\title{
Knowledge Sharing, Absorptive Capacity, and Innovation in the Brazilian Apple Production Chain
}

\author{
Compartilhamento do Conhecimento, Capacidade Absortiva e Inovação na Cadeia de \\ Produção da Maçã Brasileira
}

\author{
Gabriela Zanandrea1 \\ Cristiane Froehlich ${ }^{2}$ \\ Claudia Cristina Bitencourt ${ }^{3}$ \\ Maria Emilia Camargot ${ }^{4}$
}

\begin{abstract}
An innovative and highly technological spirit characterizes the Brazilian agribusiness sector. This sector is important not only for generating wealth but also for the growth of other economic sectors. In this context, knowledge sharing has been treated as an antecedent of innovation but not always considering the role of absorptive capacity. In the agribusiness context, this relationship is still less explored. We propose a structural equations model to analyze the relationship between knowledge sharing, absorptive capacity, and its influence on innovation in the Brazilian apple production chain. We use a quantitative-descriptive methodology to validate the model and the proposed hypotheses, empirically investigated based on a survey. We apply a questionnaire with 166 actors from the apple value chain, from the production and packing-houses segments of Southern Brazil. The results provided strong support for hypothesized relationships, which demonstrated that knowledge sharing significantly influences innovation in the Brazilian apple production chain. However, it must be integrated with the absorptive capacity to maximize its effects.
\end{abstract}

Keywords: Knowledge Sharing. Absorptive Capacity. Innovation. Agribusiness.

\section{Resumo}

O setor do agronegócio brasileiro se caracteriza por um espírito inovador e altamente tecnológico. É importante não apenas pelo seu aspecto de geração de riquezas, mas também por ser responsável pela movimentação de outros setores da economia do país. Nesse contexto, o compartilhamento de conhecimento tem sido tratado como um antecedente da inovação, mas nem sempre considerando o papel da capacidade absortiva. No contexto do agronegócio essa relação ainda é menos explorada. Desse modo, neste artigo, propõe-se um modelo de equações estruturais para analisar a relação entre compartilhamento do conhecimento, capacidade absortiva e sua influência na inovação na cadeia produtiva da maçã brasileira. Para validar o modelo e as hipóteses propostas, adotou-se a estratégia metodológica do tipo quantitativa-descritiva, investigado empiricamente através de uma survey, com 166 atores da cadeia produtiva da maçã, dos segmentos de produção e packing-houses dos Estados de Santa Catarina e Rio Grande do Sul. Os resultados sugerem que a capacidade absortiva medeia o impacto do compartilhamento de conhecimento na inovação.

Palavras-chave: Compartilhamento de Conhecimento. Capacidade Absortiva. Inovação. Agronegócio.

Ph.D. in Administration at the University of Caxias do Sul (UCS), with a sandwich doctorate in the University of Aveiro, Portugal (2018). Currently, she is a post-doctoral researcher fellow in Administration at Unisinos, Porto Alegre, Brazil. Post-Doctorate in Business Administration at Unisios. Academic Coordinator of Lato Sensu Postgraduate Courses at Feevale University.

Ph.D. in Business Administration from UFRGS, Brazil. Currently, she is a full professor and researcher at Unisinos Graduate Program in Business; Scientific director of ANPAD (Brazilian Academy of Management); Member of the International Councils AACSB/LATAM and IAJBS. and Production Engineering at UCS. Coordinator of the Graduate Program in Production Engineering at UCS. 


\section{INTRODUCTION}

Discontinuities in the economic and social arena increase the importance of knowledge and accelerate the pace of innovation to support competitiveness in changing business environments (Moustaghfir \& Schiuma, 2013). Questions about innovation and factors that influence innovation have driven the interest of academics and practitioners over the decades. Innovation is highlighted as an essential factor for the prosperity and growth of organizations and all economies (Schumpeter, 1934).

Innovation implies the successful exploitation of new ideas that contribute to business performance (Dasgupta \& Gupta, 2009), understanding its background becomes essential (Kang \& Lee, 2017). Knowledge has been considered a propellant in the current economy and crucial for organizations to survive (Wang \& Wang, 2012). The knowledge management process has gained attention among different disciplines due to the positive impact on innovation, performance, and competitive advantage (Dang \& Umemoto, 2009; Joshi et al., 2014).

Asrar-ul-Haq and Anwar (2016) point out that if knowledge is not well managed or shared, it can be easily lost, especially when it comes to tacit knowledge. In this way, knowledge sharing is identified as one of the most critical knowledge management processes vital to the organization's success and is often adopted as a survival strategy (Witherspoon et al., 2013). In this process, knowledge is transferred between individuals, groups, teams, and organizations (Wang \& Wang, 2012, Asrar-ul-Haq \& Anwar, 2016).

However, research indicates a relevant but not always addressed construct for effective performance in knowledge management, absorptive capacity (Grandinetti, 2016). We believe that exposing knowledge is not enough. Companies and individuals must be able to absorb this knowledge (Gunsel et al., 2011). Castaneda et al. (2018) argue that the main trends in the knowledge management literature address the innovation associated with the absorptive capacity. Moreover, we pointed out that most of these studies are based on data from technology-intensive companies while little evidence is available in knowledge-intensive sectors (Andreeva \& Kianto, 2011). Hence, the importance of expanding studies in other industries and observing how these elements behave in other contexts, such as in agribusiness (Dasgupta \& Gupta, 2009).

For the agricultural sector, "it is necessary to find and implement new innovative ways of creating, providing and acquiring value to be able to face existing challenges and emerging opportunities" (Vesperi et al., 2021, pp. 322). In this way, agribusiness organizations need to acquire shared knowledge and acquire it through partners to generate innovation and new knowledge (Chen et al., 2018). We based our research on the assumption that knowledge sharing is essential for agribusiness organizations to innovate and achieve superior performance. and absorptive capacity is a primordial factor to take advantage of the available knowledge.

The innovative and highly technological spirit characterizes the Brazilian agribusiness sector. Innovations explain 58.4\% of the country's agricultural productivity growth. Agricultural innovations come in many forms: they incorporate new knowledge and technologies to introduce new or improved seeds, vaccines, equipment, and cultivation techniques, in the different stages: production, processing, and commercialization. They also cover the application of quality protocols, management improvements, and access to new markets and products (Pomareda \& Hartwich, 2006).

We explore these issues in the Brazilian apple value chain. Brazilian agribusiness has contributed significantly to balance the country's trade balance, as it continually presents positively. In addition, the sector contributes to the country's economic development through the supply of products to the domestic market, absorption of a significant contingent of labor, and generates foreign exchange from exports (Martha Júnior \& Ferreira Filho, 2012).

This sector faces rapid changes and is constantly faced with new challenges. In Brazil, the apple value chain is formed by several links that allow the integration of all activities of fruit production. It includes the primary inputs to the final product, being inputs suppliers, producers, packing houses, and distributors, inserted in an organizational environment supported by institutions such as ABPM, AGAPOMI, EPAGRI, FRUTIPAR, Embrapa, and Universities (Motta, 2010).

Apple production is divided into three production centers located in southern Brazil. This chain has a prominent role in the Brazilian agribusiness, being the first chain to implement the international standards of Integrated Fruit Production (IFP) and Integrated Apple Production (IAP). These certifications provide parameters for the use of pesticides and fertilizers, pest control, soil management, packaging, and other chain processes. In addition to demonstrating their concern with the needs presented by the consumer market, they ratify the role of a pioneer innovation segment in Brazilian agribusiness (Cruz et al., 2012).

The innovations implanted in the Brazilian apple value chain involve mostly product and process innovations, according to a study developed by Cruz (2013). Therefore, the innovative activities analyzed in this study are oriented to product and process innovation, which prevail in the chain studied.

Innovation is necessary to face the complex and multifaceted environment. This research, therefore, contributes by proposing and empirically testing the relationship between these constructs, relating the process of knowledge sharing, absorption capacity, and innovation in the context of the Brazilian apple production chain, allowing a better understanding when filling such a gap. The purpose of this paper is to analyze the relationship between knowledge sharing, absorptive capacity, and innovation in the apple value chain of the Southern Region of Brazil from the links of production and packing houses. 


\section{RESEARCH MODEL AND HYPOTHESES}

\subsection{Innovation in the Agricultural Sector}

The agriculture sector needs to provide healthy, safe, and nutritious food for the world growing population, in addition to providing food for the farm animal population and fuel for a growing range of industrial uses, without depleting the Earth resources, water, and available biodiversity (OECD, 2013). Therefore, it is essential to stimulate innovation in this sector (OCDE, 2013).

In Brazil, technological innovations, an increase in automation, and agricultural mechanization changed the profile of agribusiness. In the last 40 years, technological innovations were responsible for a $58.4 \%$ growth in agricultural products. This result reinforces the importance of investing in innovation and technological development for the sector. (Sebrae/RJ, 2020).

Innovation has been highlighted as the principal driver of agricultural productivity growth and sustainability (OECD, 2013; Läpple, Renwick \& Thorne, 2015; Ozcelik, 2016) and involves the continuous use of new and existing knowledge that comes from different internal and external sources (Mutenje et al., 2016).

Innovations in the agricultural sector were seen as arising from a linear process involving the participation of public sector research and extension institutes. However, it is currently defended that agricultural innovation emerges from the interaction between different actors, such as agricultural systems, the supply chain, shaped by institutions, practices, behaviors, and social relations in a specific context. (Läpple, Renwick \& Thorne, 2015; Mutenje et al., 2016). Agricultural innovation involves interactions between different individuals or systems, which interact and share knowledge (Läpple, Renwick, Cullinan \& Thorne, 2016; Dolinska; D’aquino, 2016).

Therefore, absorptive capacity and knowledge sharing are critical factors for innovation, especially in agribusiness. The research model in this work tries to demonstrate that the absorptive capacity influences, from mediation, the relation between knowledge sharing and innovation. Figure 1 represents the research model.

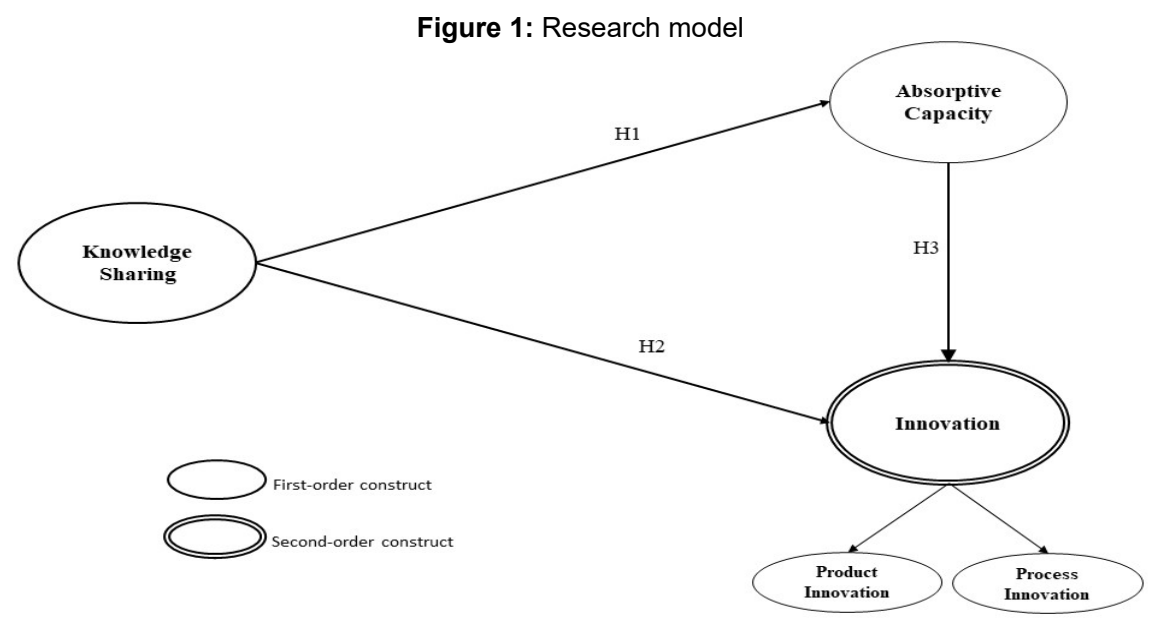

Source: By the authors.

\subsection{Knowledge Sharing and Absorptive Capacity}

Theoretical assumptions have emphasized the relationship between knowledge sharing and absorptive capacity (Oliveira et al., 2015, Lee et al., 2014). Knowledge sharing stimulates absorptive capacity. The exchange of knowledge between individuals generates new knowledge by increasing their absorptive capacity (Lee et al., 2014).

According to Sun (2010), the exploration dimension of absorptive capacity underlies the sharing activity, since acquired, assimilated, and transformed knowledge must be explored in new routines (Sun, 2010). According to Oliveira et al. (2015), the benefits of sharing are only observed when knowledge is absorbed. The authors complement that "knowledge sharing exposes individuals to new knowledge, but if these individuals cannot recognize the value of that knowledge and use it, sharing is ineffective" (Oliveira et al., 2015, p. 134).

Liao et al. (2007) developed and tested a framework that found that absorptive capacity is an intervening factor between knowledge sharing and innovation capability. The authors also showed that sharing knowledge has a positive effect on absorption, mediating innovation. These findings imply that the company must absorb shared knowledge to influence innovation and performance (Liao et al., 2007). Rafique et al. (2018) argue that the knowledge flow in organizations raises their absorptive capacity. These arguments lead to the first research hypothesis. 


\subsection{Knowledge sharing and Innovation}

Innovation depends heavily on the knowledge, skills, and experience of employees. Therefore, knowledge sharing becomes a relevant contribution to innovation as people learn from their and others ' knowledge (Wang \& Wang, 2012).

Practices such as interaction, feedback, explanation, help, or counseling stimulate individuals to think together. These practices result in changing ideas about styles and work processes, creating new knowledge structures or routines, approaches, disciplines, and cultures that favor innovation (Kamaşak \& Bulutlar, 2010, Ghazali et al., 2014).

The experience exchanged between individuals affects them mutually, and this interaction allows a higher flow of knowledge within organizations (Souza \& González-Loureiro, 2016). Flow is only facilitated when individuals and organizations exchange their knowledge (Park \& Kang, 2009). Sharing involves a reciprocal relationship regarding knowledge exchange (Mom et al., 2007). If the flow is enough and efficient among the actors, the knowledge they have is integrated, stored, and later used to generate innovations (Fang et al., 2011). It is reiterated that this knowledge is shared with collaborators, customers, suppliers, partners, and even competitors (Jantunen et al., 2008).

Empirical evidence has demonstrated the relationship between knowledge sharing and innovation. For example, Ghazali et al. (2014) indicated that knowledge sharing is related to innovation, which has ensured the organization's success and maintained its competitive advantage.

The study developed by Jantunem (2005) corroborates this result, suggesting that knowledge sharing is positively related to business innovation. Lin (2007) also noted that sharing helps companies improve innovation capability by allowing the circulation of new ideas, processes, products, or services. Similar results were indicated by Sáenz et al. (2009) in Spanish industrial companies.

Similarly, the empirical data found by Oliveira et al. (2015) suggest a significant relationship between sharing and innovation since sharing encourages individuals to be more critical and creative.

Sharing is essential in the diffusion of new technologies and scientific development to promote innovation (Bosetti et al., 2008). In addition, studies have shown that a company can improve its knowledge and innovations through knowledge sharing (Easterby et al., 2008). Based on these arguments, the following hypothesis states that:

H2: Knowledge sharing is positively related to innovation.

\subsection{Absorptive Capacity and Innovation}

Knowledge-based assets may be closely linked to innovation. The development of absorptive capacity becomes a competitive differential (Cassol, Zapalai, \& Cintra, 2017). However, even if the organization is aware of the new technology and is willing to adopt it, its ability to assimilate and explore this new process can limit the adoption rate (Micheels \& Nolan, 2016). Organizations need to absorb their knowledge to implement them in innovative projects.

Absorptive capacity was a term introduced by Cohen and Levinthal (1990), which refers to the ability to value, assimilate and apply knowledge for commercial purposes. Individuals absorb new knowledge related to their current knowledge, experiences, or training (Mariano \& Casey, 2015). In addition, individuals' skills and motivation are also relevant aspects of this ability (Liao, Fei, and Chen, 2007). Organizations need to access their prior knowledge to assimilate and use new knowledge since the accumulation of before knowledge increases the potential for future learning (Gonzalez and Martins, 2017).

At this point, several studies point to the positive effect of absorptive capacity on different aspects of innovation (Gellynck et al., 2015). When knowledge is accessed and adopted new perspectives and insights are provided, and creative ideas are triggered, consequently influencing innovations (Kang \& Lee, 2017).

Su et al. (2013) demonstrate that when firms lack this capacity, they cannot easily value, assimilate and exploit knowledge by limiting the amount of knowledge that can be used to develop innovative projects. Gunsel et al. (2011) comment that organizations need to absorb knowledge to implement innovations effectively.

Rafique, Hameed, and Agha (2018) pointed out that absorptive capacity development must be studied in different contexts as its indirect effects, such as moderation or mediation in their study on the sharing of knowledge, learning, and organizational commitment. The third research hypothesis is based on these arguments.

H3: Absorptive capacity mediates the relationship between knowledge sharing and innovation. 


\section{METHOD}

\subsection{Sample and Data Collection}

To validate the model and test the proposed hypotheses, we use a quantitative-descriptive method, empirically investigated based on a survey. We apply a questionnaire with 166 actors in the apple value chain from production and packing houses segments of Rio Grande do Sul and Santa Catarina. The size was scaled from the assumptions of Marôco (2014) of at least three respondents per scale variable.

The states the Rio Grande do Sul and Santa Catarina were selected because they represented more than $98.8 \%$ of the total production of Brazil. We chose the sector due to the importance of agribusiness to the Brazilian economy. Specifically, the fruit sector has been showing growth over the years. For example, between 2006-2012, the variation in exports increased by 23.1\%, from 739 US \$ million in 2006 to $\$ 910$ million in 2012 (MAPA, 2017).

In this context of the production and fruit business, the apple is relevant economically and socially. Brazil ranks among the 13th biggest producers in the world regarding the quantity produced, with an average annual production of $1,264,651 \mathrm{~kg}$ of fruit (Faostat, 2017). Nationally, the apple is one of the most produced fruits $\left(8^{\mathrm{a}}\right)$, besides being among the most consumed (3rd). The sector is responsible for handling around $\mathrm{R} \$ 6$ billion in the entire production chain and generating the employability index of 195 thousand jobs, 58.5 thousand direct jobs, and 136.5 thousand indirectly (Kist et al., 2016). According to MAPA (2019), there is an upward trend in apple production over the next ten years, principally due to the density of orchards and greater technological adherence in producing regions.

The sample of producers included small, medium, and large ones, whose function is to carry out the land management to produce the fruit. As for the packing houses, it is important to note that these represent companies responsible for the classification, packaging, and storage of the apple. Therefore, these subjects were chosen because they had information and knowledge related to the production chain.

\subsection{Measures}

For the data collection, we used a structured questionnaire using a five-point Likert scale ( 1 = strongly disagree; $5=$ strongly agree) through electronic form link sending by e-mail or by direct contact with the respondents.

The proposed indicators were adapted from existing instruments used in previous research. The scale that evaluates knowledge sharing was adapted from Andreeva and Kianto (2011) to assess the knowledge sharing among the actors (Table 1).

Table 1: Constructs e search variables

\begin{tabular}{ll}
\hline \multicolumn{1}{c}{ Constructs } & \multicolumn{1}{c}{ Observable variables } \\
\hline & $\begin{array}{l}\text { KS1 - In my organization, information and knowledge are actively shared amond } \\
\text { employees } \\
\text { KS2 - In my organization, employees and manegers exchange a lot of information and } \\
\text { Knowledge Sharing }\end{array}$ \\
& $\begin{array}{l}\text { KS3 - My organization shares knowledge and information with strategic partness } \\
\text { KS4 - Our employees are systematically informed of changes in procedures, } \\
\text { instructions and regulations }\end{array}$ \\
\hline
\end{tabular}

Source: By authors

For absorptive capacity, the chosen scale was proposed by Yoo et al. (2011) because it seeks to capture the ability of the organization to recognize the value, assimilate and apply new knowledge successfully (Table 2). 
Table 2: Constructs e search variables

\begin{tabular}{ll}
\hline \multicolumn{1}{c}{ Constructs } & \multicolumn{1}{c}{ Observable variables } \\
\hline & My Organization \\
& AC1 - Have the ability to use existing knowledge. \\
& AC2 - Have the ability to recognize the value of new information or knowledge. \\
Absorptive Capacity - Have the ability to link their knowledge with the knowledge of others. & AC4 - Have the ability to integrate various views of team members. \\
& AC5 - Have the ability to apply basic knowledge to the creation of new knowledge. \\
\hline
\end{tabular}

Source: By authors.

The items to measure innovation were based on the instrument proposed by Trienekens et al. (2008) to measure innovation in the apple chain (Table 3).

Table 3: Constructs e search variables

\begin{tabular}{ll}
\hline \multicolumn{1}{c}{ Constructs } & \multicolumn{1}{c}{ Observable variables } \\
\hline & My Organization \\
& IPRO1 - Develops new products, clones or cultivars \\
& IPRO2 - Invests in the production of fruits that respect the environment \\
Product Innovation & IPRO3 - Invests in improving the quality of its products \\
& IPRO4 - Invests in research to find new varieties of products \\
& IPRO5 - Deleted Products Quickly Replaced \\
& My Organization \\
& IPCE1 - Invests in the acquisition of new machines \\
IPCE2 - Invests in the improvement of work processes & et al. (2008) \\
IPCE3 - Looking to adopt latest production technologies \\
IPCE4 - Responds quickly to customer needs \\
IPCE5 - Is flexible to provide products according to customers' demands
\end{tabular}

Source: By authors.

\subsection{Data Analysis Technique}

We analyzed the collected data through Structural Equation Modeling. This technique was selected because we wanted to verify if the model simulated from the theory represents the empirical reality. However, before applying this technique, preliminary data treatment was necessary to prove possible data missions and the presence of outliers (Z score, Mahalanobis). Besides, the analyzes of normality (asymmetry), multicollinearity (VIF and tolerance factor), and linearity (Pearson Test). After the performance of the tests, it was verified that data attend the assumptions for the multivariate analysis, enabling applying the Structural Equation Modeling using AMOS statistical software.

\section{RESULTS}

\subsection{Measurement Model}

To assess the quality of the measurement model, we examined the indicators of internal consistency, reliability, convergent validity, and discriminant validity. First, we test reliability based on Cronbach's alpha, and composite reliability, whose values were higher than 0.7 (as postulated in Table 4), showing that the constructs used are reliable (Bagozzi \& Yi, 1988). Then, for the convergent validity measure, we used the Mean Extracted Variance, for which the limit value was 0.5 (Fornell \& Larcker, 1981). Consequently, all constructs have convergent validity (Table 4). The final test for scale quality is discriminant validity. In this case, the most used test in the literature is the criterion of Fornell-Larcker (1981), which suggests that the AVE of each latent variable should be higher than the square correlations with all other latent variables (Table 4).

Moreover, most of the indicators have loads for the respective constructs, indicating that the values of the AVE (main diagonal) are higher than the values of the shared variance (below the diagonal), guaranteeing the discriminant validity for all the items. 
Table 4: Results of reliability and validity tests

\begin{tabular}{ccccccc}
\hline & CA & CR & SH & AC & IPRO & IPCE \\
\hline SH & 0,88 & 0,88 & $\mathbf{0 , 6 5}$ & & & \\
AC & 0,81 & 0,81 & 0,06 & $\mathbf{0 , 5 1}$ & & \\
IPRO & 0,79 & 0,78 & 0,12 & 0,27 & $\mathbf{0 , 4 7}$ & \\
IPCE & 0,81 & 0,81 & 0,04 & 0,03 & 0,11 & $\mathbf{0 , 4 9}$ \\
\hline
\end{tabular}

Notes: $\mathrm{CA}=$ Cronbach's Alpha; $\mathrm{CR}=$ Composite Reliability; AVE = Average Bariance Extracted; $\mathrm{SH}=$ Knowlodge Sharing; $\mathrm{AC}=\mathrm{Absorptive} \mathrm{Capacity;} \mathrm{IPRO} \mathrm{=} \mathrm{Product}$ Innovation; IPCE = Process Innovation.

Source: By authors.

The results of the confirmatory factorial analysis showed that all the scales used in the study formed adequate measurement models and provided evidence for the construct validity of the measurements.

\subsection{Structural Model and Hypotheses Testing}

After satisfying the requirements discussed in the previous item, the hypothetical model was tested, summarizing the three hypotheses proposed. We described the analyses in Figure 2 and Table 5, pointing out that all hypotheses were supported.

$\mathrm{H} 1$ - we analyzed the direct effect of knowledge sharing and absorptive capacity, in which the results confirm the positive relationship between these two constructs $(\beta=0.25, p=0.007)$ (Figure 2). H2 - we tested the direct relationship between knowledge sharing and innovation. The results showed that the total effect of knowledge sharing on innovation is positive and significant $(\beta=0.25 ; p=0.000)$, confirming the $\mathrm{H} 2$ hypothesis (Figure 2$)$.

Figure 2: Results of the structural model testing

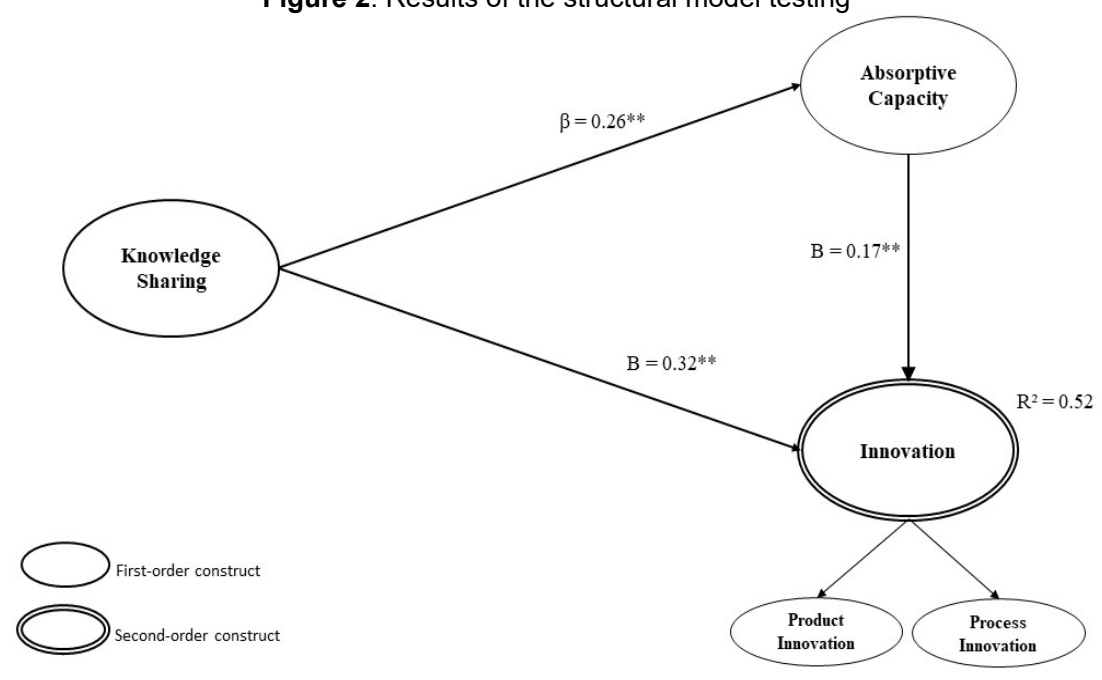

Source: By the authors.

We tested the effect of the absorptive capacity as mediating variable of the relationship between knowledge sharing and innovation $(\mathrm{H} 3)$. Initially, the absorptive capacity has positive and significant direct effect on innovation $(\beta$ $=0.35, p=0.000)$. Subsequently, mediation was calculated from Sobel's test according to Baron and Kenny (1986).

This approach assumes a non-standardized coefficient for path $X \rightarrow M$ and that SEa is the standard error. $E$ and SEb, respectively, represent the same things for the path to $M \rightarrow Y$. Where $X$ is the independent variable (in this, knowledge sharing), $M$ is the mediator variable (in this, absorptive capacity) and $Y$ is the dependent variable in this, innovation) (Kline, 2011). The product $a \times b$ estimates the non-standard indirect effect of $X$ on $Y$ through $M$. The estimated standard error of Sobel from $a x b$ is (Kline, 2011):

$$
\text { Sobel Test }=\frac{a x b}{\sqrt{a^{2} S E a^{2}+b^{2} S E b^{2}}}
$$


The ab / SEab ratio is interpreted as the non-standard indirect effect $z$ test (Kline, 2011). Therefore, the result of this equation is expected to remain above or below \pm 1.96 , with a confidence interval of 95 (Sobel, 1982). In this study, the Sobel test proved the mediation effects, whose results were satisfactory (Sobel $=2.38, p<0.01$ ). Table 5 present the mediators' effects of the proposed model.

Table 5: Mediators effects of the proposed model

\begin{tabular}{clccccc}
\hline Condition & \multicolumn{1}{c}{ Relationship } & $\boldsymbol{\beta}{ }^{*}$ & SE & CR & P & Sobel \\
\hline Isolated & Knowledge sharing $\rightarrow$ Absorptive Capacity & 0.253 & 0.093 & 2.715 & 0.007 & \\
Isolated & Knowledge sharing $\rightarrow$ Innovation & 0.255 & 0.072 & 3.523 & 0.000 & \\
Isolated & Absorptive Capacity $\rightarrow$ Innovation & 0.357 & 0.072 & 4.974 & 0.000 & 2.38 \\
& Knowledge sharing $\rightarrow$ Innovation & 0.176 & 0.062 & 2.691 & 0.007 & \\
\cline { 2 - 6 } Joint & Absorptive Capacity $\rightarrow$ Innovation & 0.321 & 0.070 & 4.59 & 0.000 & \\
& & &
\end{tabular}

Source: By the authors.

The results indicate there is the intervention of the mediator variable in the effect of knowledge sharing on innovation. We observe that the absorptive capacity partially mediates the relationship between knowledge sharing and innovation (Hair Jr. et al., 2009), since the values of non-standardized $\beta$ of the influence of knowledge sharing and innovation, after insertion of the mediator variable, reduced, were significant $(\beta=0.255, p=0.000$ for $\beta=0.176, p=0.007)$.

Figure 2 presents the structural model with the standardized $\beta$ values and the $r^{2}$ values, where the antecedents explain $52 \%$ of the innovation construct proposed.

\section{DISCUSSIONS AND IMPLICATIONS}

This study supports the idea that knowledge is considered a valuable resource for achieving a competitive advantage (Zander \& Kogut, 1995; Grant, 1996). In addition to providing empirical evidence linking knowledge sharing and innovation, this study suggests that absorptive capacity acts as a variable mediating this relationship.

We evidenced the positive relationship between knowledge sharing and innovation which states that knowledge sharing should be facilitated to allow the company a superior competence in sharing and be successful in innovation performance.

Besides, we also find a positive influence of knowledge sharing on absorptive capacity. This finding is consistent with different studies found in the literature applied in other sectors. They also showed the positive and significant influence of knowledge sharing on the absorptive capacity (Oliveira et al., 2006; Liao et al., 2007).

The findings support the view that knowledge sharing and absorptive capacity should not be seen in isolation but interrelated and, therefore, relevant innovation antecedents. These results correspond to Kang and Lee`s (2017) ones that the absorptive capacity mediates the relation between knowledge sharing and innovation.

Garrido et al. (2017) also observed similar results when analyzing the mediating effect of absorptive capacity on the relationship between past performance and innovativeness. It also implies that the companies with the highest absorptive capacity level are better prepared to recognize the value in new knowledge and dedicate efforts in their assimilation, transformation, and application for commercial purposes, obtaining better results related to innovation (Garrido et al. 2017).

The results indicate that organizations should promote efforts to share knowledge among team members, other companies, and institutions. However, at the same time, it requires the development of the absorptive capacity to identify, assimilate and develop knowledge for the innovation process and consequent to gain the sustainable competitive advantage essential for their survival.

Apple production involves high risk due to climatic conditions impacts and the rise in production costs, economic instability, and exchange rate changes. Therefore, decision-making processes must be accurate. Previous experience and specific knowledge are essential to ensure an adequate return, always seeking to reduce losses. Under these conditions, the exchange of knowledge between actors in the production chain is vital.

These actors should focus on structuring systems that facilitate knowledge sharing to mobilize tacit and explicit knowledge. Tacit knowledge is obtained from the skills and experiences of actors, while explicit knowledge is found in institutionalized approaches and practices involving apple production. When there is a stimulus for sharing, the actors in the chair are likely to generate new ideas, develop new opportunities, and facilitate innovation activities.

Although knowledge is a critical factor for other Brazilian agribusiness chains, the findings of this research are based on data from actors in the apple production chain. Therefore, we believe they are relevant to other chains, but they should be viewed cautiously when generalized to different contexts. Future research, however, should investigate the constructs addressed in this thesis in other production chains, verifying their behavior in another agribusiness context.

By the importance of the agricultural sector for the countries`economies, especially for the Brazilian economy, this study contributes to the emerging issues approach that is still scarce treated in this context. Organizations from 
different sectors are interested in innovating and achieving better performance, especially agribusiness actors. In this way, the results obtained here can provide additional guidance to leverage knowledge sharing and absorptive capacity to generate innovation and improve performance and competitive advantage.

Therefore, organizations in the apple value chain should strive to promote different ways to enable practical experiences and skills, scientific research results, expert opinions, and other types of knowledge necessary to develop the chain. To this end, new dynamics can be used to share knowledge, where collaboration and joint learning between producers and others, who are responsible for the creation and dissemination of knowledge, should be prioritized, as must the different actors of the chain in the process of generating this knowledge so that these users legitimize these.

\section{REFERENCES}

ANDREEVA, T.; KIANTO, A. Knowledge processes, knowledge-intensity and innovation: a moderated mediation analysis. Journal of Knowledge Management, [s. I.], v. 5, n. 6, p. 1016-1034, 2011.

ASRAR-UL-HAQ, M.; ANWAR, S. A systematic review of knowledge management and knowledge sharing: trends, issues, and challenges. Cogent Business \& Management, [s. I.], v. 3, n. 1, p. 1-17, 2016.

BAGOZZI, R. P.; YI, Y. On the evaluation of structural equation models. Journal of the Academy of Marketing Science, [s. I.], v. 16, n. 1, p. 74-94, 1988.

BANCO REGIONAL DE DESENVOLVIMENTO DO EXTREMO SUL. Superintendência de Planejamento. Cadeia produtiva da maçã no Brasil: limitações e potencialidades. Porto Alegre: BRDE, 2011.

BOSETTI, V.; CARRARO, C.; MASSETTI, E.; TAVONI, M. International energy R\&D spillovers and the economics of greenhouse gas atmospheric stabilization. Energy Economics, [s. I.], v. 30, n. 6, p. 2912-2929, 2008.

BRASIL. Ministério da Agricultura, Pecuária e Abastecimento. Projeções do agronegócio Brasil 2018/19 a 2028/29: projeções de longo prazo. Brasília: MAPA, 2019.

CASSOL, A.; ZAPALAI, J.; CINTRA, R. F. Capacidade absortiva como propulsora da inovação em empresas incubadas de Santa Catarina. Revista Ciências Administrativas, Fortaleza, v. 23, n.1, p. 9-41, 2017.

CASTANEDA, D. I.; MANRIQUE, L. F.; CUELLAR, S. Is organizational learning being absorbed by knowledge management? A systematic review. Journal of Knowledge Management, [s. I.], v. 22, n. 2, p. 299-325, 2018.

CASTRO, G. M. Knowledge management and innovation in knowledge-based and high-tech industrial markets: the role of openness and absorptive capacity. Industrial Marketing Management, [s. I.], v. 47, p. 143-146, 2015.

CHEN, H.; LIU, S.; ZHAO, G.; ODERANTI, F.; GUYON, C.; BOSHKOSKA, B. M. Identifying knowledge brokers, artefacts and channels for waste reduction in agri-food supply chains. International Journal of Sustainable Agricultural Management and Informatics, [s. I.], v. 4, n. 3-4, p. 273-289, 2018.

COHEN, W. M.; LEVINTHAL, D. A. Absorptive capacity: a new perspective on learning and innovation. Administrative Science Quarterly, [s. I.], v. 35, n. 1, p. 128-152, 1990.

CRUZ, M. R. D. Relacionamento na cadeia produtiva da maçã sob a ótica da teoria da complexidade. 2013. Tese (Doutorado em Administração) - Universidade de Caxias do Sul, Caxias do Sul, 2013.

CRUZ, M. R.; CAMARGO, M. E.; MALAFAIA, G. C.; ZANANDREA, G. Produção integrada de maçã (PIM) - processo inovador na cadeia produtiva da maçã brasileira. RAI-Revista de Administração e Inovação, [s. I.], v. 9, n. 3, p. 213-230, 2012.

DANG, D.; UMEMOTO, K. Modeling the development toward the knowledge economy: a national capability approach. Journal of Knowledge Management, [s. I.], v. 13, n. 5, p. 359-372, 2009.

DASGUPTA, M.; GUPTA, R. K. Innovation in organizations: a review of the role of organizational learning and knowledge management. Global Business Review, [s. I.], v. 10, n. 2, p. 203-224, 2009.

DOLINSKA, A.; D'AQUINO, P. Farmers as agents in innovation systems. Empowering farmers for innovation through 
communities of practice. Agricultural Systems, [s. I.], v. 142, p. 122-130, 2016.

EASTERBY-SMITH, M.; LYLES, M. A.; TSANG, E. W. Inter-organizational knowledge transfer: current themes and future prospects. Journal of Management Studies, [s. I.], v. 45, n. 4, p. 677-690, 2008.

FANG, S. R.; FANG, S. C.; CHOU, C. H.; YANG, S. M.; TSAI, F. S. Relationship learning and innovation: the role of relationship-specific memory. Industrial Marketing Management, [s. I.], v. 40, n. 5, p. 743-753, 2011.

FAOSTAT. Crops. Food and Agriculture Organization (FAO), Roma-Italia, [2021]. Disponível em: http://www.fao. org/faostat/en/\#data/QC/visualize. Acesso em: 1 jun. 2017.

FORNELL, C.; LARCKER, D. F. Evaluating structural equation models with unobservable variables and measurement error. Journal Of Marketing Research, [s. I.], v.18, n.1, p. 39-50, Feb.1981.

GARRIDO, I. L.; PARENTE, R. C.; GONÇALO, C. R.; VASCONCELLOS, S. L. D. Remaining innovative: the role of past performance, absorptive capacity, and internationalization. BBR - Brazilian Business Review, [s. I.], v. 14, n. 6, p. 559-574, 2017.

GELLYNCK, X.; CÁRDENAS, J.; PIENIAK, Z.; VERBEKE, W. Association between innovative entrepreneurial orientation, absorptive capacity, and farm business performance. Agribusiness, [s. I.], v. 31, n. 1, p. 91-106, 2015.

GHAZALI, N. I.; LONG, C.; GHAZALI, N. Knowledge sharing factors and innovation capability. In: TECHNOLOGY, INFORMATICS, MANAGEMENT, ENGINEERING, AND ENVIRONMENT (TIME-E), 2., 2014, Indonesia. Proceedings [...]. Indonesia: IEEE, 2014. p.315-320.

GRANDINETTI, R. Absorptive capacity and knowledge management in small and medium enterprises. Knowledge Management Research \& Practice, [s. I.], v. 14, p.159-168, 2016.

GRANT, R. M. Toward a knowledge-based theory of the firm. Strategic Management Journal, [s. I.], v. 17, n. 2, p. 109-122, 1996.

GONZALEZ, R. V. D.; MARTINS, M. F. Knowledge management process: a theoretical-conceptual research. Gestão \& Produção, [s. I.], v. 24, n. 2, p. 248-265, 2017.

GUNSEL, A.; SIACHOU, E.; ACAR, A. Z. Knowledge management and learning capability to enhance organizational innovativeness. Procedia-Social and Behavioral Sciences, [s. I.], v. 24, p. 880-888, 2011.

HAIR, J. F.; BLACK, W. C.; BABIN, B. J.; ANDERSON, R. E.; TATHAM, R. L. Análise multivariada de dados. Porto Alegre: Bookman, 2009.

JANTUNEN, A. Knowledge-processing capabilities and innovative performance: an empirical study. European Journal of Innovation Management, [s. I.], v. 8, n. 3, p. 336-349, 2005.

JANTUNEN, A.; PUUMALAINEN, K.; HURMELINNA-LAUKKANEN, P. Knowledge sharing and innovation performance. Journal of Information \& Knowledge Management, [s. I.], v. 7, n. 3, p. 187-195, 2008.

JOSHI, K. D.; NISSEN, M. E.; COOPER, L. Introduction to knowledge flows: knowledge transfer, sharing, and exchange minitrack. In: HAWAII INTERNATIONAL CONFERENCE ON SYSTEM SCIENCES (HICSS), 47., 2014, Waikoloa. Proceedings [...]. Waikoloa: IEEE, 2014. p. 3488-3488.

KAMAŞAK, R.; BULUTLAR, F. The influence of knowledge sharing on innovation. European Business Review, [s. I.], v. 22, n. 3, p. 306-317, 2010.

KANG, M.; LEE, M. J. Absorptive capacity, knowledge sharing, and innovative behaviour of R\&D employees. Technology Analysis \& Strategic Management, [s. I.], v. 29, n. 2, p. 219-232, 2017.

PARK, H. W.; KANG, J. Patterns of scientific and technological knowledge flows based on scientific papers and patents. Scientometrics, [s. I.], v. 81, n. 3, p. 811-820, 2009. 
KIST, B. B. et al. Anuário Brasileiro da Maçã 2016. Santa Cruz do Sul: Gazeta, 2016.

LÄPPLE, D.; RENWICK, A.; CULLINAN, J.; THORNE, F. What drives innovation in the agricultural sector? A spatial analysis of knowledge spillovers. Land use Policy, [s. I.], v. 56, p. 238-250, 2016.

LÄPPLE, D.; RENWICK, A.; THORNE, F. Measuring and understanding the drivers of agricultural innovation: evidence from Ireland. Food Policy, [s. I.], v. 51, p. 1-8, 2015.

LEE, J.; LEE, H.; PARK, J. G. Exploring the impact of empowering leadership on knowledge sharing, absorptive capacity and team performance in IT service. Information Technology \& People, [s. I.], v. 27, n. 3, p. 366-386, 2014.

LIAO, S. H.; FEI, W. C.; CHEN, C. C. Knowledge sharing, absorptive capacity, and innovation capability: an empirical study of Taiwan's knowledge-intensive industries. Journal of Information Science, [s. I.], v. 33, n.3, p. 340-359, 2007.

LIN, H. F. Knowledge sharing and firm innovation capability: an empirical study. International Journal of Manpower, [s. I.], v. 28, n. 3/4, p. 315-332, 2007.

MARIANO, S.; CASEY, A. Is organizational innovation always a good thing?. Management Learning, [s. I.], v. 46, n. 5, p. 530-545, 2015.

MARÔCO, J. Análise estatística com o SPSS statistics. 6. ed. Lisboa: Report Number, 2014.

MICHEELS, E. T.; NOLAN, J. F. Examining the effects of absorptive capacity and social capital on the adoption of agricultural innovations: a canadian prairie case study. Agricultural Systems, [s. I.], v. 145, p. 127-138, 2016.

MARTHA JÚNIOR, G. B.; FERREIRA FILHO, J. B. de S. Brazilian agricultural development and changes. Brasília: EMBRAPA, 2012.

MOM, T. J.; VAN DEN BOSCH, F. A.; VOLBERDA, H. W. Investigating managers' exploration and exploitation activities: the influence of top-down, bottom-up, and horizontal knowledge inflows. Journal of Management Studies, [s. I.], v. 44, n. 6 , p. 910-931, 2007.

MOTTA, M. E. V. Análise sistêmica da cadeia produtiva da maçã na região sul do Brasil: uma perspectiva do desempenho. 2010. Dissertação (Mestrado em Administração) - Universidade de Caxias do Sul, Caxias do Sul, 2010.

MOUSTAGHFIR, K.; SCHIUMA, G. Knowledge, learning, and innovation: research and perspectives. Journal of Knowledge Management, [s. I.], v. 17, n. 4, p. 495-510, 2013.

MUTENJE, M.; KANKWAMBA, H.; MANGISONIB, J.; KASSIE, M. Agricultural innovations and food security in Malawi: gender dynamics, institutions and market implications. Technological Forecasting and Social Change, [s. I.], v. 103, p. 240-248, 2016.

ORGANIZATION FOR ECONOMIC CO-OPERATION AND DEVELOPMENT. Agricultural innovation systems: a framework for analysing the role of the government. Paris: OECD, 2013.

OLIVEIRA, M.; CURADO, C. M.; MAÇADA, A. C.; NODARI, F. Using alternative scales to measure knowledge sharing behavior: are there any differences? Computers in Human Behavior, [s. I.], v. 44, p. 132-140, 2015.

OZCELIK, A. E. Driving initiatives for future improvements of specialty agricultural crops. Computers and Electronics in Agriculture, [s. I.], v. 121, p. 122-134, 2016.

POMAREDA, C.; HARTWICH, F. Innovación agrícola en América Latina: comprendiendo el papel del sector privado. Washington: International Food Policy Research Institute, 2006.

RAFIQUE, M.; HAMEED, S.; AGHA, M. H. Impact of knowledge sharing, learning adaptability and organizational commitment on absorptive capacity in pharmaceutical firms based in Pakistan. Journal of Knowledge Management, [s. I.], v. 22, n.1, p. 44-56, 2018.

SÁENZ, J.; ARAMBURU, N.; RIVERA, O. Knowledge sharing and innovation performance: a comparison between 
high-tech and low-tech companies. Journal of Intellectual Capital, [s. I.], v. 10, n. 1, p. 22-36, 2009.

SCHUMPETER, J. A. The theory of economic development: an inquiry into profits, capital, credit, interest, and the business cycle. Cambridge: Harvard University Press, 1934.

SERVIÇO DE APOIO ÀS MICRO E PEQUENAS EMPRESAS DO ESTADO DO RIO DE JANEIRO. Mapeamento do setor agrícola: inovações, tendências e oportunidades. Rio de Janeiro: Sebrae, 2020.

SHUJAHAT, M.; SOUSA, M. J.; HUSSAIN, S.; NAWAZ, F.; WANG, M.; UMER, M. Translating the impact of knowledge management processes into knowledge-based innovation: the neglected and mediating role of knowledge-worker productivity. Journal of Business Research, [s. I.], v. 94, p. 442-450, 2019.

SOBEL, M. Asymptotic intervals for indirect effects in structural equations models. In: LEINHART, S. (ed.). Sociological methodology. San Francisco: Jossey-Bass, 1982. p. 290-312.

SOUSA, M. J.; GONZÁLEZ-LOUREIRO, M. Employee knowledge profiles-a mixed-research methods approach. Information Systems Frontiers, [s. I.], v. 18, n. 6, p. 1103-1117, 2016.

SU, Z.; AHLSTROM, D.; LI, J.; CHENG, D. Knowledge creation capability, absorptive capacity, and product innovativeness. R\&D Management, [s. I.], v. 43, n. 5, p. 473-485, 2013.

SUN, P. Five critical knowledge management organizational themes. Journal of Knowledge Management, [s. I.], v. 14, n. 4, p. 507-523, 2010.

TRIENEKENS, J.; VAN UFFELEN, R.; DEBAIRE, J.; OMTA, O. Assessment of innovation and performance in the fruit chain: the innovation-performance matrix. British Food Journal, [s. I.], v. 110, n. 1, p. 98-127, 2008.

VESPERI, W.; MELINA, A. M.; VENTURA, M.; COPPOLINO, R.; REINA, R. Organizing knowledge transfer between university and agribusiness firms. Systems Research and Behavioral Science, [s. I.], v. 38, p. 321-329, 2021.

WANG, Z.; WANG, N. Knowledge sharing, innovation and firm performance. Expert systems with applications, [s. I.], v. 39, n. 10, p. 8899-8908, 2012.

WITHERSPOON, C. L.; BERGNER, J.; COCKRELL, C.; STONE, D. N. Antecedents of organizational knowledge sharing: a meta-analysis and critique. Journal of Knowledge Management, [s. I.], v. 17, n. 2, p. 250-277, 2013.

YOO, D. K.; VONDEREMBSE, M. A.; NATHAN, T. S. R. Knowledge quality: antecedents and consequence in project teams. Journal of Knowledge Management, [s. I.], v. 15, n. 2, p. 329-343, 2011.

ZANDER, U.; KOGUT, B. Knowledge and the speed of the transfer and imitation of organizational capabilities: an empirical test. Organization Science, [s. I.], v. 6, n. 1, p. 76-92, 1995.

ZOUAGHI, F.; SÁNCHEZ, M. Has the global financial crisis had different effects on innovation performance in the agri-food sector by comparison to the rest of the economy? Trends in Food Science \& Technology, [s. I.], v. 50, p. 230-242, 2016. 


\section{Contato:}

Gabriela Zanandrea

E-mail: gabi.zanandrea@gmail.com

Cristiane Froehlich

E-mail: froehlich.cristiane@gmail.com

Claudia Cristina Bitencourt

E-mail: claudiacb@unisinos.br

Maria Emilia Camargo

E-mail: mariaemiliappga@gmail.com 